\title{
DRY BENEFICIATION OF KYANITE ORES
}

\author{
A. I. Urvantsev ${ }^{1}$ and I. D. Kashcheev ${ }^{2}$
}

Translated from Novye Ogneupory, No. 6, pp. 10 - 12, June, 2013.

Original article submitted February 4, 2013.

The beneficiation of kyanite ores by a new dry technology is studied. Compared to the flotation method, the method reduces energy consumption from $300-400$ to $15-25 \mathrm{kWh} /$ ton. Dry electroseparation has made it possible to obtain concentrates with an $\mathrm{Al}_{2} \mathrm{O}_{3}$ content of $59-60 \%$ while also producing pure quartz ("tailings").

Keywords: kyanite, beneficiation, energy efficiency, electroseparation.

Metastable minerals of the sillimanite group (andalusite, sillimanite, and kyanite), having the general formula $\mathrm{Al}_{2} \mathrm{O}_{3} \cdot \mathrm{SiO}_{2}$ and theoretical contents of $\mathrm{Al}_{2} \mathrm{O}_{3}$ and $\mathrm{SiO}_{2}$ respectively equal to 62.9 and 37.1 mass $\%$, are widely used as an alumosilicate raw material in the refractories industry. The volumes of andalusite, sillimanite, and kyanite increase 4,8 , and $16-18 \%$ during roasting. Thus, the first two minerals are used directly in refractories production, while kyanite needs to undergo a preliminary roasting operation.

A large percentage of the deposits of metastable minerals in the world are mined by opencast method. The average content of the useful component in the ores is $10-15 \%$ and the reserves total 1 million tons. The methods of beneficiation that are used include crushing, classification, separation based on density, and flotation (which is the most effective method of obtaining high-quality concentrates). The commercial product contains $56-59 \% \quad \mathrm{Al}_{2} \mathrm{O}_{3}, 38-40 \%$ $\mathrm{SiO}_{2}$, and less than $3 \%$ impurities.

The main producers of concentrates of minerals in the sillimanite group are South Africa, the U. S., India, France, and Brazil. In Russia, most of the kyanite reserves are located in the Urals and Karelia. The projected reserves of kyanite in the Karabash deposit are estimated to be 10 million tons and have a mineral content $\sim 25 \%$. The total volume of the ore is approximately 40 million tons.

By its very nature, wet beneficiation invariably entails the consumption of large quantities of water, and subsequent washing of the converter requires the use of heat to remove the moisture. The use of water and fuel has an unavoidable negative impact on the economics of the production process.

1 OOO “Russkaya Korona," Ekaterinburg, Russia.

2 Ural Federal University, Ekaterinburg, Russia.
Thus, the elimination of wet beneficiation and its replacement by dry beneficiation is an important problem in the processing of kyanite concentrate.

The main method employed in Russia for the beneficiation of kyanite ores is based on flotation and entails the use of flotation reagents to remove sulfides in the initial part of the process and subsequent flotation of kyanite from sulfide flotation tailings. The reagents used in the sulfide flotation are xanthogenate and aerofoil, while the reagent in the kyanite flotation is sulfonate in an acid medium (in the presence of sulfuric acid). The number of operations performed in sulfide flotation reaches six [1, pp. 203 - 207]. The flotation operation is complicated by the presence of sulfides and graphite.

Flotation technology requires comminution to $\sim 50 \%$ of the $-0.071 \mathrm{~mm}$ fraction, in addition to subsequent drying of the kyanite concentrates from a moisture content in the range $15-20 \%$. The tailings are not seen to have any value as prospective quartz products.

In a dry technology employing electroseparation, comminution is carried out to $\sim 50 \%$ of the $-0.2 \mathrm{~mm}$ fraction ( $100 \%$ of the $-0.315-0.4 \mathrm{~mm}$ fraction). The sulfide and graphite minerals are easily removed by corona-electrostatic separation, while the dry quartz tailings become a commercial product for certain sectors of industry. The OOO "Russkaya Korona" has developed a technology for the beneficiation of mineral resources - including kyanite ores through the use of cold drying and electroseparation [2]. The method makes it possible to reduce energy consumption in the beneficiation process from the $300-400 \mathrm{kWh} /$ ton crude ore seen in flotation to $15-25 \mathrm{kWh} /$ ton [3]. The technology does not use water, flotation reagents, or organic fuel, which eliminates emissions of reagents and heat. 
To evaluate the beneficiating ability of the dry technology, we used a representative sample having the following mineral composition, mass \%: kyanite 27.0 ; quartz 70.0 ; muskovite, sericite 1.0 ; garnet 0.5 ; ilmenite 1.0 ; iron hydroxide 0.5 .

To perform tests, the initial sample was ground to a coarseness of $-0.315 \mathrm{~mm}$. In preliminary tests [4], before electroseparation the initial sample was completely dried and heated to $100-150^{\circ} \mathrm{C}$ - as has traditionally been recommended [5]. The test scheme included dry magnetic separation in $2-3$ stages. The results from the beneficiation operation are presented in Table 1, which shows that at a yield of $\sim 27 \%$ the content of $\mathrm{Al}_{2} \mathrm{O}_{3}$ in the kyanite concentrate is $\sim 57 \%$ ( $\sim 90 \%$ based on kyanite). At a yield of $73 \%$, the tailings contain $1.5-1.8 \% \mathrm{Al}_{2} \mathrm{O}_{3}, 0.15 \% \mathrm{Fe}_{2} \mathrm{O}_{3}$, and $0.3 \% \mathrm{TiO}_{2}$. The amount of kyanite recovered in the concentrate was $\sim 91.7 \%$.

Table 2 shows comparative results from the electroseparation of untreated kyanite concentrates with the use of different thermal regimes for the separation process. In test 1 , the initial untreated kyanite concentrate, with a coarseness of $-0.315+0.0 \mathrm{~mm}$, was subjected to pneumoelectric separation in air having a temperature $\sim 18^{\circ} \mathrm{C}$ and a relative humidity of $8-10 \%$. The concentrate was not

TABLE 1. Results from the Pneumoelectric Separation of Kyanite Ore from the Karabash Deposit, \%

\begin{tabular}{lcccccc}
\hline \multirow{2}{*}{ Beneficiation products } & Yield & \multicolumn{3}{c}{ Content } & \multicolumn{2}{c}{$\begin{array}{c}\text { Recovery } \\
\text { of kyanite }\end{array}$} \\
\cline { 3 - 6 } & & $\mathrm{Al}_{2} \mathrm{O}_{3}$ & $\mathrm{SiO}_{2}$ & $\mathrm{Fe}_{2} \mathrm{O}_{3}$ & $\mathrm{TiO}_{2}$ & 0.4 \\
Kyanite concentrate & 27.0 & 57.0 & 38.2 & 0.60 & 91.7 \\
Tailings & 73.0 & $1.5-1.8$ & 96.2 & 0.15 & 0.3 & 8.3 \\
Initial ore & 100.0 & 16.8 & 80.6 & 0.40 & 0.3 & 100.0 \\
\hline
\end{tabular}

TABLE 2. Results from the Pneumoelectric Separation of Untreated Kyanite Concentrates in Relation to Temperature and Moisture Content

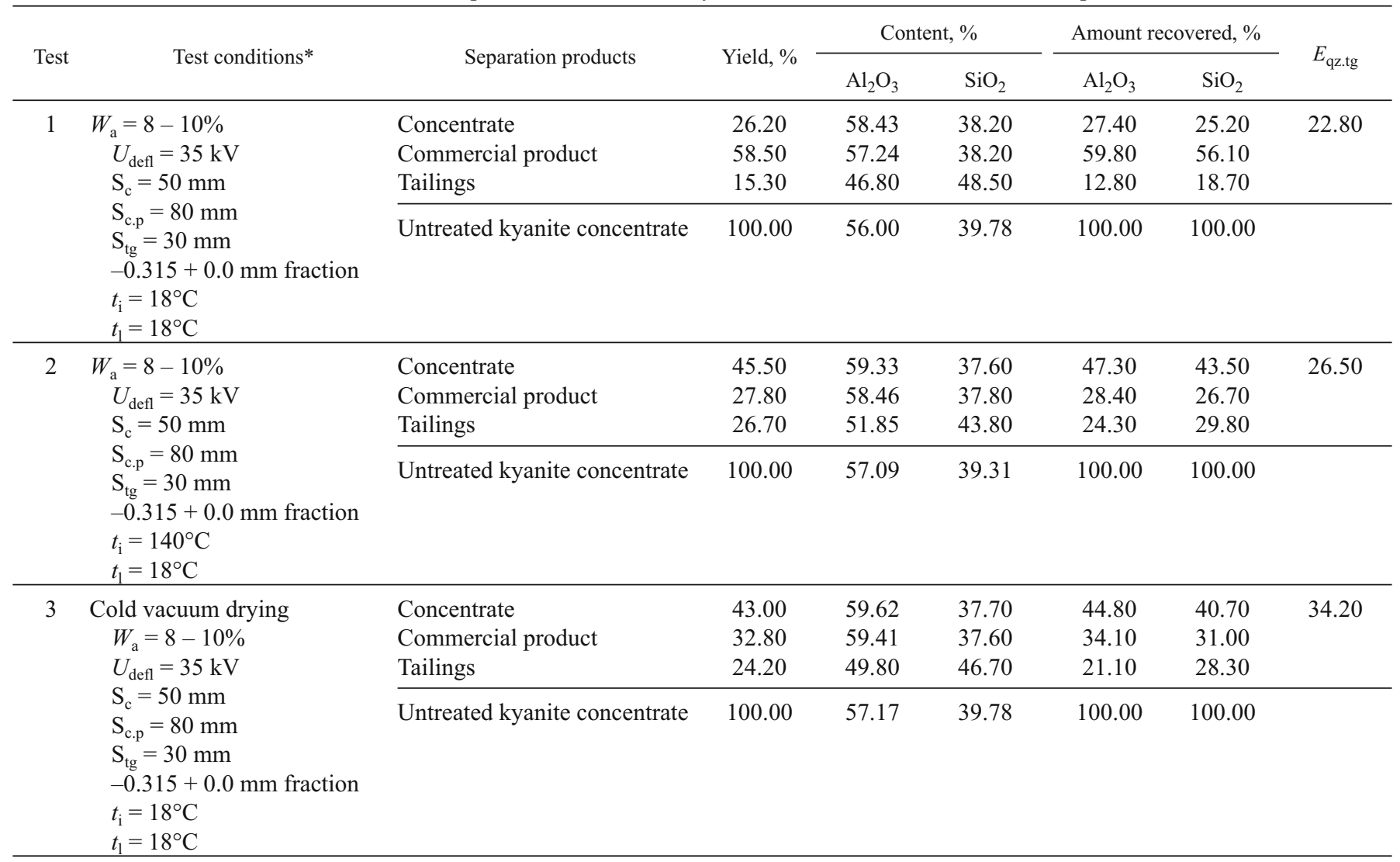

\footnotetext{
* $W_{\mathrm{a}}$ ) relative humidity of the air; $U_{\text {defl }}$ ) voltage (potential difference on the deflecting electrodes creating the electrostatic field; $S_{\mathrm{c}}, S_{\mathrm{s} . \mathrm{p}}, S_{\mathrm{tg}}$ ) size (width of the holes for the concentrate, commercial product, and tailings - the separation products; $t_{\mathrm{i}}$ ) temperature of the initial ore fed into the separator; $t_{1}$ ) temperature of the air in the laboratory; $E_{\mathrm{qz.tg}}$ ) efficiency of extraction of free quartz in the tailings; cold vacuum drying) the parameters for the use of a new energy-saving method of drying.
} 
heated in this test. The particles of the initial mixture were subjected to triboelectric charging on a screen by the method described in [6].

It can be seen that the product being separated does not fan out enough without heating. The yield of the commercially useful fraction is $58.5 \%$. In test 2 , which involved heating of the initial material (by the method in [5], the yield of concentrate increased from 26.2 to $45.5 \%$ and its $\mathrm{Al}_{2} \mathrm{O}_{3}$ content rose to $59.3 \%$. The yield of tailings also increased, from $15.3 \%$ (in test 1 ) to $26.7 \%$ in test 2 . Thus, the efficiency with which free quartz was recovered in the tailings increased to $26.5 \%$ when the material was heated. In test 3 , with "cold" drying by a new method [2], the amount of $\mathrm{Al}_{2} \mathrm{O}_{3}$ in the concentrate and the commercial product obtained by electroseparation was even higher than for the initial raw material heated to $140^{\circ} \mathrm{C}$ in the second test. Thus, the efficiency with which free quartz was recovered from the tailings became the highest in the series and reached $34.2 \%$.

\section{CONCLUSION}

Studies were made of a dry technology for the electroseparation of kyanite ores that has made it possible to obtain concentrates with $59-60 \% \mathrm{Al}_{2} \mathrm{O}_{3}$ (up to $95 \%$ for the mineral) and $\sim 37-38 \% \quad \mathrm{SiO}_{2}$ while also producing pure quartz tailings. It was established that unit energy costs for the dry technology are cut to $15-25 \mathrm{kWh} / \mathrm{ton}$, and there is an accompanying sharp reduction in the amount of production wastes generated thanks to elimination of the need for process water, flotation reagents, and organic fuel.

\section{REFERENCES}

1. E. E. Kameneva and L. S. Skal'nitskaya, Beneficiation of Mineral-Bearing Raw Materials in Karelia [in Russian], Karelian Research Center of the RAN (Russian Academy of Sciences), Petrozavodks (2003).

2. A. I. Urvantsev, I. A. Urvantsev, and D. A. Urvantsev, Russian Federation Patent Claim No. 2012113683. Method of Beneficiating Minerals, Submitted 11.04.12.

3. A. I. Urvantsev, "Physical foundations and current technical applications of energy-saving technologies of the OPI," Planck Lectures 2011: Proc. Internat. Conf. (Verkhnyaya Pyshma, Sept. 19 - 24, 2011). Fort-Dialog-Iset', Ekaterinburg (2011), pp. 295-297.

4. A. I. Urvantsev, N. V. Shikhov, and G. V. Zaitsev, "Research findings and the practice of beneficiating mineral-bearing raw materials by electroseparation," Izv. Vyssh. Uchebn. Zaved. Gorn. Zh., No. 5, 37 - 51 (2005).

5. Solid Incombustible Minerals. Engineering Methods of Studying Mineral-Bearing Raw Materials. Electrical Methods of Beneficiation. STO GosGEO 08-004-98. RosGeo, Moscow.

6. A. I. Urvantsev, "Features of the triboelectric charging of particles in pneumoelectric separators," Improving Electroseparation Processes and Electroseparator Designs: Interdepartmental Symposium, Mekhanobr, Leningrad (1987), pp. 36 - 46. 